\title{
EFFECT OF CONSUMING TOMATO (SOLANU MLYCOPERSICUM L) JUICE AND RED SPINACH (AMARANTHUS TRICOLOR L) ON HAEMOGLOBIN LEVELS OF REPRODUCTIVE AGE WOMEN IN PAYUNG SEKAKI PUBLIC HEALTH CENTER, PEKANBARU
}

\author{
Resda Pebriani, Rifa Yanti
}

School of health sciences Al-Insyirah Pekanbaru

\begin{abstract}
Background: Anemia is a nutritional problem that affects millions of people in developing countries and remains a significant challenge for human health. This study aimed to determine the effect of giving a combination of tomato juice and red spinach on haemoglobin levels of reproductive age women in Payung Sekaki Community Health Center, Pekanbaru. Subjects and Method: This study was a experimental study with pretest and posttest one group design conducted in the working area of the Umbrella Sekaki Community Health Center Pekanbaru.A sample of 27 people was selected by purposive sampling. The dependent variable was an increase in hemoglobin levels in women of childbearing age. The independent variable was tomato and spinach juice. The data were collected by digital $\mathrm{Hb}$ set, a scale, a measuring cup.

Results: Hemoglobin of women of reproductive age before being given intervention (Mean= 10.97; $\mathrm{SD}=0.563$ ) was higher after giving intervention (Mean = 11.68; $\mathrm{SD} 0.536)$ and statistically significant with ( $\mathrm{p}>0.05)$.

Conclusion: There is an effect of giving a combination of tomato juice (Solanu Mlycopersicum L) and red spinach (Amaranthus Tricolor L) on Haemoglobin levels in WUS in the working area of in Payung Sekaki Community Health Center, Pekanbaru.
\end{abstract}

Keywords: Combination of Tomato Juice and Spinach, Haemoglobin level.

\section{Correspondence:}

Resda Pebriani, School of health sciences Al-Insyirah Pekanbaru. Mustafa Sari No.5, Tengkerang Sel, Kec. Bukit Raya, Kota Pekanbaru, Riau. Email: pebrianiresda24@gmail.com. Mobile: 081231304336. 